\title{
The dynamics of cancer stem cells
}

\author{
Minireview $^{* *}$
}

J. HATINA

Charles University, Faculty of Medicine in Pilsen, Department of Biology, Karlovarska 48, CZ-30166 Plzen, Czech Republic

Correspondence: jiri.hatina@lfp.cuni.cz

Received March 29, 2012 / Accepted June 19, 2012

\begin{abstract}
With the formulation of the hierarchical model of tumor cell organization, cancer stem cells came to the forefront of cancer biology. As the only self-renewing tumor cells, they were made responsible for continuous tumor growth and their intrinsic self-protection ability was postulated to underlie cancer therapy resistance and/or recurrence. The concept of migrating cancer stem cells extended the relevance of the hierarchical cancer cell model to issue of cancer progression, with the crucial experimental evidence being provided by the demonstration that epithelial mesenchymal transition can convey stemness. Accordingly, cancer stem cells probably represent a highly dynamic cell population continuously differentiating and being continuously replenished by processes like mesenchymal epithelial transition and epithelial mesenchymal transition, respectively. Consequently, from the point of view of therapeutic targeting, cancer stem cells obviously do not represent a fixed target population any longer. Understanding the dynamic nature of cancer stem cells is thus essential not only for the progress in our understanding of basic cancer biology, but also from the therapeutic perspective.
\end{abstract}

Key words: cancer stem cells, epithelial mesenchymal transition, epithelial-stromal interactions, cell culture models

The concept of cancer stem cells has been formulated during the late 1990s as an alternative to the clonal selection model. Both of these models address the issue of tumor heterogeneity; in the latter, tumor heterogeneity is regarded as a result of a constant process of mutagenesis and selection. Tumor cell population is genetically unstable, continuously spawning new genetic cell variants which are subject to selection, with the fittest variants displacing the more benign cells. All the cells of a tumor have the same capacity for this clonal evolution, i.e. all are similarly dangerous and to cure the disease, they should be all eradicated [1].

The cancer stem cell model is based on the notion that this equivalence of all tumor cells regarding the probability of their long-term proliferation and progression does not hold true. Accordingly, tumors would represent a sort of aberrant tissue governed by the same principles as those operating in normal continuously renewing tissues. Only a fraction of cells is endowed with the capacity for long-term proliferation. These cancer stem cells both self-renew and differentiate into progeny with a limited proliferative capacity. In addition, the cancer stem cells, like normal stem cells, are equipped with various self-protecting mechanisms. Consequently, according to this hierarchical model of tumor organization, it is not true that all tumor cells are equally dangerous. The cancer stem cells, lying at the top of the proliferation hierarchy, are those that are mainly responsible for driving continuous tumor growth and progression, and, by virtue of their self-protecting mechanisms, for cancer recurrence as well. As a corollary, curing cancer means to eradicate first and foremost this stem cell population [2-9]. This "classical" stem cell model was challenged in the last few years by several findings showing that the stem cell population is by far more dynamic than

${ }^{*}$ Presented on the XX. Biological Days - Stem cells - from regenerative medicine to cancer, Pilsen, October 25-27, 2011 
what was presented in the original cancer stem cell model. It is increasingly recognized that cancer stem cells are themselves a heterogeneous mixture of different subpopulations, with an extensive exchange among them. In addition, both differentiation and dedifferentiation processes can take place within tumors. The goal of this review is to summarize the current knowledge on cancer stem cells, with a special emphasis on these recently identified aspects of this crucial and special cancer cell population.

The "classical" cancer stem cell model. The fact that not all cancer cells are biologically equal was suggested already in the 1960s by several tumor transplantation experiments. Only a small fraction of mouse myeloma cells could form splenic colonies in transplanted mice [10] and a similar conclusion came previously out of an ethically questionable human tumor autotransplantation study [11]. Later, clonogenic assays in semisolid media in frames of human tumor in vitro chemosensitivity testing found a very low clonogenic efficiency of certain tumors. These clonogenic cells were, in these experiments, termed tumor stem cells and it was assumed that an optimal chemotherapeutic regimen, the finding of which was the final goal of this procedure, should target and eliminated these clonogenic stem cells [12]. In the same period, biological analysis of testicular cancer in mouse defined a clear stem cell component, with differentiation ability into cell types of all the three germ layers (e.g. neurons, hair, bone and muscle) within tumors and even an apparently unlimited differentiation ability when injected into mouse blastocystes. Importantly, with the advent of cisplatin-based curative chemotherapy for testicular cancer in humans, it was possible to detect differentiated tumor-originating cells with no tendency to resume proliferation in former cancer patients, even years after their cure [reviewed in ref. 4].

All these separate observations could be formulated into a general cancer stem cell model once it became possible to prospectively separate different cancer cell populations by flow cytometry and test them for their ability to initiate cancer upon their transplantation into immunodeficient mice. The first successful story was the acute myeloid leukaemia, with leukaemia transplantation capacity uniquely concentrated into $\mathrm{CD} 34^{+} \mathrm{CD} 38^{-}$cells, i.e. into the population expressing the marker profile identical to normal haematopoietic stem cells [13]. Solid tumors came later, with breast and brain cancers leading the way. It is an irony of history that it came recently out that the $\alpha-C D 38$ antibody used in this first successful cancer stem cell sorting experiment can be recognized and mediate elimination of corresponding antigen expressing cells by the residual immune system of recipient mice, allowing for a far less spectacular explanation of the preferential leukaemogenic capacity of the CD34+ ${ }^{+}$D $38^{-}$cells [14]. Nevertheless, the hierarchical cancer model could be successfully established by these transplantation experiments.

In addition to the use of specific cell surface marker molecules or their combinations, another approach was developed to prospectively purify putative cancer stem cells. It is based on the existence of extensive self-protection mechanisms - a property shared with normal somatic stem cells. Two of these mechanisms were developed into very useful purification methods. The side population (SP) sorting is based on the constitutive expression of ATP binding cassette (ABC)-efflux pumps, actively expelling fluorescent dies like Hoechst 33342 and allowing the purification of dim cells after this staining $[15,16]$. The aldefluor assay relies on the constitutive expression of the detoxifying enzyme aldehyde dehydrogenase H1A1 [reviewed in refs. 17, 18]. Table 1 lists the most extensively used stem cell markers and table 2 gives some examples of successful application of different stem cell purification strategies. Notice that for most tumors, several different strategies have been independently exploited and the stem cells identified for a given tumor type using different purification strategies need not to be identical (see accompanying paper by Zeimet et al.).

Irrespective of the mode of isolation, the cancer stem cells are believed to be the only tumor cell population capable of self-renewing. All the other cells of the tumor would represent their less or more differentiated descendant cells with only a limited proliferative capacity. A typical response of a tumor to therapy consists in reduction or complete elimination of these descendant progeny cells, whereas cancer stem cells largely survive due to their self-protection ability, resulting in disease recurrence after a latency period of variable length. Tumor progression consists in accumulating mutations in this special cancer stem cell population, frequently limiting their differentiation potency [ 2-9].

Biological properties and origin of cancer stem cells. Key biological characteristics of cancer stem cells include the above cited triad - self-renewal ability, differentiation capacity and self-protection. In (xeno)transplantation experiments, a commonly used biological assay to evidence cancer stem cells, these properties lead to their exclusive tumorigenicity, yielding tumors that represent phenocopies of the original tumor, from which they were isolated, i.e. restoring the original tumor heterogeneity [2-9].

When considering this issue in more detail, several other characteristics become apparent. Put into sparse adherent cell culture, stem cells of either normal epithelial tissues or well differentiated carcinomas generate very compact colonies of typical morphology called holoclones, being composed of small cells of pronounced epithelial character; importantly, only these colonies are serially clonogenic, implying that stem cell self-renewal takes place within them. Differentiation in these experimental conditions takes the form of producing colonies of increasingly large, flat and loosely connected cells. Such colonies - meroclones and finally paraclones - do not yield holoclones by subcloning, whereas subcloning of holoclones gives regularly all the three colony types. In fact, meroclones and paraclones could be barely serially subcloned at all, implicating a loss of stemness concomitant with their differentiation $[19,20]$. Essentially all the tumorigenicity of carcinomas is represented in carci- 
noma holoclones, paraclones are non-tumorigenic $[21,22]$. In nonadherent cell culture conditions, stem cells produce unique floating aggregates called spheres $[23,24]$. Analogi- cally to holoclones, cancer spheres concentrate essentially all the tumorigenic capacity of the cancer cell population [25]. Again, this sphere-forming capacity is shared between

Table 1. Stem cell and cancer stem cell markers in current use

\begin{tabular}{|c|c|}
\hline Marker & Biological function and practical use \\
\hline CD44 & $\begin{array}{l}\text { CD44 plays a dual role, both as a cell surface adhesion molecule and hyaluronan and osteopontin receptor. Its expression } \\
\text { features a rather complex alternative splicing, generating at least } 11 \text { variant transcripts. CD44 has been extensively used for } \\
\text { cancer stem cell enrichment in various tumors (prostate, ovary, bladder, breast, pancreas, etc.). In addition to this property } \\
\text { as a mere marker, it seems to be functionally involved in various biological processes, including lymphocyte homing, cancer } \\
\text { metastasis and peritoneal colonization. As a receptor molecule, its signal transduction may activate the expression of several } \\
\text { stem cell specific genes, like Nanog or ABC efflux pumps. }\end{array}$ \\
\hline CD133 & $\begin{array}{l}\text { CD133 is a glycosylated transmembrane cell surface antigen identified as a marker of various stem and progenitor cells, in- } \\
\text { cluding haematopoietic stem cells, circulating endothelial precursors, and numerous cancer stem cell populations (lung, liver, } \\
\text { prostate, colon, ovary, pancreas, etc.). Its relevance for cancer stem cell identification has been questioned. Both its expression } \\
\text { and its specific glycosylation can change upon cell differentiation. }\end{array}$ \\
\hline CD326 & $\begin{array}{l}\text { CD326 (Epithelial Specific Antigen - ESA = Epithelial specific Cell Adhesion Molecule - EpCAM) is a pan-epithelial differ- } \\
\text { entiation antigen expressed on the basolateral surface of various carcinomas. It acts as a homotypical cell adhesion molecule } \\
\text { and can modulate various oncogenic signal molecules, like Cadherin - Catenin of c-Myc. }\end{array}$ \\
\hline CD33 & $\begin{array}{l}\text { CD33 is a cell surface adhesion molecule of myelomonocytic cells that belongs to the SIGLEC family of lectins and binds } \\
\text { sialic acid. Its specific expression in AML and CML leukaemic stem cells could provide a potential therapeutic target. }\end{array}$ \\
\hline CD34 & $\begin{array}{l}\text { CD34 is a cell surface adhesion molecule typical for haematopoietic stem and precursor cells and endothelial progenitors, as } \\
\text { well as leukaemic stem cells. }\end{array}$ \\
\hline CD123 & $\begin{array}{l}\text { CD123 represents the } \alpha \text {-chain of the interleukin-3 receptor and is expressed on both haematopoietic stem cells and various } \\
\text { normal haematopoietic cell lineages, as well as on leukaemic stem cells. Its specifically increased expression in AML leukaemic } \\
\text { stem cells could provide a potential therapeutic target. }\end{array}$ \\
\hline CD29 & $\begin{array}{l}\text { CD29 is the } \beta_{1} \text { integrin expressed in basal cells of stratified epithelia, e.g. in skin or urothelium, as well as on the corresponding } \\
\text { transformed cells. Its expression has also been reported in mesenchymal stem cells. }\end{array}$ \\
\hline CD49f & $\begin{array}{l}\mathrm{CD} 49 \mathrm{f} \text { is the } \alpha_{6} \text { integrin expressed on a variety of cells. As a stem cell marker, it proved to be valuable for purification of nor- } \\
\text { mal mammary as well as breast cancer stem cells, cervical cancer stem cells, stem cells of normal urothelium and prostate, } \\
\text { as well as bladder cancer stem cells. }\end{array}$ \\
\hline $\mathrm{CD} 24$ & $\begin{array}{l}\mathrm{CD} 24 \text { is a membrane sialoglycoprotein that binds glycosylphosphatidilinositol. Due to a specific posttranslational processing } \\
\text { and/or membrane transport and insertion, its expression is low to absent on breast cancer stem cells, whereas it is expressed } \\
\text { on normal mammary epithelial stem cells, as well as on pancreatic cancer stem cells. }\end{array}$ \\
\hline CD166 & $\begin{array}{l}\text { CD166 was reported to characterize both the stem cell fraction of colorectal carcinoma and mesenchymal stem cells. Its high } \\
\text { expression on tumor cells might represent a poor prognosis indicator for colorectal carcinoma patients. }\end{array}$ \\
\hline CD90 & $\begin{array}{l}\text { CD90 (Thy-1) is expressed on a wide spectrum of cell types, like T-cells, neurones, endothelial cells and fibroblasts, and, ac- } \\
\text { cordingly, is implicated in various biological processes, like T-cell activation, neurite outgrowth, apoptosis, as well as cancer } \\
\text { growth. As a specific cancer stem cell marker, it was used for purification of hepatocellular carcinoma stem cells, and recently } \\
\text { also bladder carcinoma stem cells. }\end{array}$ \\
\hline ALDH1A1 & $\begin{array}{l}\text { Aldehyde dehydrogenase H1A1 belongs to an extensive family of aldehyde dehydrogenases involving at least } 19 \text { genes. They } \\
\text { are involved in various metabolic processes, notably in retinoid metabolism. It seems to be a rather universal marker of vari- } \\
\text { ous normal and cancer stem cell populations (breast, ovary, bladder, liver, head and neck etc.). By virtue of its detoxification } \\
\text { activity (e.g. towards cyclophosphamide), it is involved in cancer stem cell chemoresistance. }\end{array}$ \\
\hline $\mathrm{ABCB} 1$ and $\mathrm{ABCG} 2$ & $\begin{array}{l}\text { ABCB1 (P-glycoprotein = Multidrug Resistance Protein-1 - MDR-1) and ABCG2 (Breast Cancer Resistance Protein - BCRP) } \\
\text { are members of an extensive family of ATP-binding cassette }(\mathrm{ABC}) \text { efflux pumps specifically expressed on both normal and } \\
\text { cancer stem cell populations, as well as on chemoresistant tumor cells. Being a part of stem cell self-protection, their specific } \\
\text { expression was extensively used for purification of stem cells as side population (SP). }\end{array}$ \\
\hline ABCB5 & $\begin{array}{l}\text { ABCB } 5 \text { represents a new member of the } \mathrm{ABC} \text { family, mapping to the } 7 \mathrm{p} 15.3 \text {. Basically acting in the same way as } \mathrm{ABCB} 1 \text { and } \\
\mathrm{ABCG} 2 \text {, it was particularly useful to identify and purify melanoma stem cells. }\end{array}$ \\
\hline
\end{tabular}

Stem cell surface CD markers can be both fairly universal, allowing for enrichment of stem cell fractions out of various cancerous or normal cell populations (e.g. CD44, CD133, CD326), or specific for only certain cell types. A given CD marker can be used to purify stem cells out of different tissues and tumors, and stem cells of a given tissue or tumor can be independently identified using several CD markers. Besides the specific expression of a cell surface marker molecule, a specific phenotypic trait of stem cells might be used to enrich for them in biological assays and/or to purify them. Aldehyde dehydrogenase and $\mathrm{ABC}$ efflux pumps are independently responsible for stem cell self-protection and chemoresistance, and thus represent quite universal means for stem cell identification. The expression of various ABC-efflux pumps can become ubiquitous, nevertheless, in tumors that exhibit multidrug resistance. Adapted in part from [6]. 
normal and cancer stem cells. Interestingly, all the stem cell properties discussed up to now (exquisite tumorigenicity, clonogenicity, holoclone and sphere forming ability) are preserved also in certain tumor cell lines, even after years of continuous culture.

Together with frequently common cell surface marker expression and shared self-protection mechanisms, these analogies in biological behaviour between normal and cancer stem cells lead to the obvious hypothesis that cancer stem cells arise by mutation of normal somatic stem cells. In some tissues (skin, blood, intestine), this scenario is corroborated by the short-lived nature of all cells but stem cells [2-9]. On the other hand, the majority of normal stem cells are rather quiescent. For a great part of mutations, they can only be fixed in the genome by a round of DNA replication, which limits the mutagenic potential of many of the normal stem cells types [26]. An extreme case are normal neuronal stem cells, which seem to be totally nondividing in the normal mammalian brain. In such tissues, cancer stem cells may well arise by transformation of more differentiated precursor cells instead of somatic stem cells, providing that the transforming mutations impart self-renewal [27]. For intestinal stem cells, to cite an opposite example, quiescence was recently essentially disproved and for them, it is very realistic to assume that their transformation leads to the respective cancer stem cells $[28,29]$.

One of the crucial early deregulations in basic stem cell biology distinguishing normal and cancer stem cells might address asymmetric cell division. Normal adult stem cells divide for the most part asymmetrically, producing just one stem cell and the second more differentiated precursor cell. Key to this strict regulation is the stem cell niche, a special microenvironmental structure ensuring the preservation of stemness. The asymmetric cell division might have a rather simple explanation, at least in part and in some tissues - there is no place in the stem cell niche to support the second stem cell. This mode of stem cell division leads to a long-term homeostasis in stem cell numbers in normal tissues. For cancer stem cells, this strict homeostatic regulation is certainly disturbed. Cancer growth is per definition expansive, probably tipping the balance towards symmetric cell division, where both daughter cells of a cancer stem cell inherit the stem cell nature. This could only be made possible by a substantial change in niche requirements. The existence of stem cells in pure cancer cell lines after years in culture points to some autonomy - possibly cancer cells alone are able to provide their own niche to support stem cells dispersed among more differentiated cells [3]. In tumors in vivo, a substantial part of niche providing activity might fall to tumor stroma, with cancer associated fibroblasts (CAFs) and tumor associated macrophages (TAMs) playing likely the prime role [30] (see accompanying paper of Weiland et al.).

Cancer stem cells and cancer progression. Cancer progression, according to this "classical" cancer stem cell model, consists in accumulating further oncogenic mutations in the cancer stem cell population. Certain biological properties of cancer stem cells discussed above are, however, rather difficult to reconcile with the most prominent cancer progression events, especially invasion and metastasis. For holoclones, for example, a pronounced epithelial character is the most prominent characteristic and one of the genes featuring holoclones and found as differentially expressed between holoclones and paraclones is $\mathrm{CDH} 1$ coding for E-cadherin [20]. This sort of dilemmas led to the formulation of the migrating stem cell concept [31]. It presumes heterogeneity among cancer stem cells, with stationary cancer stem cells responsible for tumor growth at the primary site, and migrating cancer stem cells, generated at the invasive front, being responsible for local invasion and metastatic dissemination. Experimental evidence for the migrating cancer stem cell model came first for the pancreatic carcinoma. Two different stem cell populations were characterized in a pancreatic carcinoma cell line as well as primary tumor samples. $\mathrm{CD} 133^{+}$cells behaved like classical cancer stem cells, i.e. they were highly tumorigenic after orthotopic transplantation. A subset of these cells, however, coexpressed CXCR4 chemokine receptor, and these CD133+ $\mathrm{CXCR}^{+}$cells were in addition highly metastatic [32]. It is noteworthy that CXCR4 is the receptor for the stromal cellderived factor-1 (SDF-1 = CXCL12), one of the principal paracrine factors secreted by cancer associated fibroblasts [30]. The tumor stroma might thus act not only as a general niche element for cancer stem cells, but also promote their progression into migrating cancer stem cells.

Further support for the migrating cancer stem cell model came with the discovery that epithelial-mesenchymal transition can impart stem cell character $[33,34]$. The epithelial-mesenchymal transition (EMT) is a crucial event related to progression in carcinomas. Carcinoma cells loose their epithelial character and undergo a morphological transition towards a fibroblast-like phenotype. Epithelial markers (E-cadherin, placoglobin, desmoplakin) are lost and mesenchymal markers (vimentin, $\mathrm{N}$-cadherin) are newly expressed. As a final result, cells loose their cell-cell adherence and become highly motile - a necessary requirement for local invasion and metastatic spread. Crucial triggers of EMT are, especially, transcription repressors of the $C D H 1$ promoter, like Snail, Slug, Twist-1, Twist-2, Zeb-1, Zeb-2, and TGF- $\beta$ [35]. Experimental EMT induced in immortalized normal human mammary epithelial cells by overexpression of Snail or Twist-1, or by TGF- $\beta$ treatment not only led to the expected phenotypic transformation, but, notably, also drastically increased the stem cell fraction, both at the level of cell surface marker profile and by functional criteria (sphere formation, tumorigenicity upon coexpression of activated Ras) [33]. Similar results were independently reported for pancreatic carcinoma cells as well [34]. Further study provided a clear mechanistic link between EMT and stem cell phenotype - one of the crucial stem cell regulatory 
factors, the global transcription regulator Bmi-1, is in fact the Twist- 1 downstream gene and synergizes with Twist-1 in E-Catherin repression, as well as in the repression of the $p 16^{I N K 4 a} / p 14^{A R F}$ locus, an event crucial to the stem cell selfrenewal [36]. Interestingly, the Twist-1 gene itself is regulated by HIF- $1 \alpha$ and thus responsive to hypoxia [37]. By this way, hypoxia can be another environmental trigger of migrating cancer stem cells, besides the tumor stroma.

The story is far from being black-and-white, however. The second hypoxia activated transcription factor, HIF- $2 a$, induces Oct-4 [38], a crucial stem and pluripotency transcription factor, especially in embryonic stem cells, that actually inhibits EMT and in fact induces the opposite process - mesenchymal-epithelial transition (MET) [39]. On the other hand, in bladder cancer a high (but still substantially lower than in embryonic stem cells) and widespread Oct-4 expression was associated with increased progression towards motility, invasion and metastasis, strongly reminiscent of ongoing EMT [40]. Does this mean that Oct-4 can exert opposing effects in embryonic stem cells and carcinoma cells, or as a function of its expression level? Such dosage dependent opposing effects of Oct- 4 on pluripotency versus differentiation of embryonic stem cells were indeed reported
[41]. Another point deserving further study is that hypoxia is not absolutely necessary to activate HIF- $1 \alpha$ and HIF-2 $\alpha$ in tumor cells. Another essential factor is mTOR (mammalian target of Rapamycin), a serin-threonin kinase representing a point of convergence of several oncogenic signal transduction pathways (e.g. PI3'K - Akt or LKB-1 - AMPK). High levels of mTOR activity can activate hypoxia inducible factors even in normoxic conditions [42]. Adding to the complexity, it was recently reported that in vitro cultured cells can display an unprecedented phenotypic plasticity, apparently switching between the stem cell phenotype and the differentiated phenotype without a necessity to pass through EMT and MET processes $[43,44]$; the molecular details of this phenomenon remain unknown.

"Dynamic" cancer stem cell concept. Should the above described concept of migrating cancer stem cell, and especially the EMT as a widespread mechanism of stem cell generation, be validated, the current stem cell concept has to be substantially modified compared to the classical one. Cancer stem cell population would be quite dynamic. Cancer stem cells derived from normal somatic stem cells or precurson cells would, on the one hand, continuously differentiate to non-self-renewing descendants, and, on the

Table 2. Identified stem cell populations in different tumors

\begin{tabular}{|c|c|c|}
\hline Tumor type & Marker(s) of cancer stem cells & Proportion of cancer stem cells identified (\%) \\
\hline Acute myeloid leukaemia & $\mathrm{CD} 34^{+} \mathrm{CD} 38^{-}$ & $<0.2$ \\
\hline Breast carcinoma & $\mathrm{ESA}^{+} \mathrm{CD} 44^{+} \mathrm{CD} 24^{- \text {-low }}$ Lineage ${ }^{-}$ & $0.6-5$ \\
\hline Breast carcinoma & $\mathrm{ALDH}^{+}$ & $3-10$ \\
\hline Colorectal carcinoma & $\mathrm{CD}_{133^{+}}$ & $0.7-25$ \\
\hline Colorectal carcinoma & $\mathrm{ESA}^{+} \mathrm{CD} 44^{+}$ & $0.03-38$ \\
\hline Head and neck cancer & $\mathrm{CD} 44^{+}$ & $0.1-42$ \\
\hline Head and neck cancer & $\mathrm{ALDH}^{+}$ & $<7$ \\
\hline Glioblastoma & $\mathrm{CD}_{133^{+}}$ & $19-29$ \\
\hline Glioblastoma & $\mathrm{CD} 44^{+}$ & $<1-88$ \\
\hline Medulloblastoma & $\mathrm{CD}_{133^{+}}$ & $6-21$ \\
\hline Pancreatic carcinoma & $\mathrm{CD}_{133^{+}}$ & $1-3$ \\
\hline Pancreatic carcinoma & $\mathrm{ESA}^{+} \mathrm{CD} 44^{+} \mathrm{CD} 24^{+}$ & $0.2-0.8$ \\
\hline Hepatocellular carcinoma & $\mathrm{CD}_{133^{+}}$ & 46.7 \\
\hline Hepatocellular carcinoma & $\mathrm{CD} 0^{+}$ & $0.03-6$ \\
\hline Hepatocellular carcinoma & $\mathrm{CD}_{133^{+}} \mathrm{ALDH}^{+}$ & 5 \\
\hline Hepatocellular carcinoma (cell lines) & Side population & $0.2-0.8$ \\
\hline Lung carcinoma (different subtypes) & $\mathrm{CD}_{133^{+}}$ & $0.3-22$ \\
\hline Melanoma & $\mathrm{ABCB}^{+}$ & $1.6-20$ \\
\hline Retinoblastoma & $\mathrm{ABCG}^{+}$ & $<1$ \\
\hline Sarcoma & Side population & $0.07-10$ \\
\hline Sarcoma & $\mathrm{ALDH}^{+}$ & 10 \\
\hline
\end{tabular}

Stem cells of the same tumor type can be identified with the aid of several different stem cell markers, and some markers can be used rather universally, allowing for identification of stem cells in different tumors. Notice the large quantitative variability in stem cell fractions identified in the majority of tumor types. This can reflect an intrinsic intertumoral variability, i.e. the large fluctuation in stem cell fractions from one individual tumor to another, or technical and methodological differences in stem cell identification procedure between different research groups. Source: $[5,8,9,15,17]$ 
other hand, these descendant cells would regain self-renewing capacity by processes like EMT, thus replenishing the cancer stem cell pool. The extent of both of these processes could be highly variable as a function of stage of progression, environmental influence, particular mutations in each individual tumor, etc. The huge variability in percentage of cancer stem cells identified in different reports, ranging from as low as $0.01 \%$ to as high as over $80 \%$ (Table 2), could, at least in part, be explained by such dynamic phenomena. From the therapeutic point of view, they complicate the matter substantially. Eradicating the entire stem cell population at a given point does not necessarily lead to a cancer cure, as implicated in the classical stem cell model, but stem cells could be readily replenished from more differentiated progeny $[7,45]$.

Nevertheless, it is still not completely certain, to what extend the EMT-induced dedifferentiation into cancer stem cells really takes place. Another possible source of migrating cancer stem cells would be the stationary cancer stem cells, and in this scenario, the cancer stem cell population as a whole could be quantitatively relatively constant in each individual tumor (with possible substantial variation among different tumors, according to the factors mentioned above), but dynamic in its biological and clinical properties. Indeed, a recent analysis in oral and cutaneous squamous cell carcinoma cell lines and primary tumor samples strongly suggested that this hypothesis might be quite probable [46]. Motile EMT-derived stem cells were identified exclusively at the periphery of holoclones. Stationary and migrating cancer stem cells would thus be two extreme phenotypes of a single stem cell pool. Moreover, both stem cell populations could undergo a morphologic transformation into each other - processes of EMT and MET are thus in dynamic equilibrium, modulated by environmental influence; tumors generated by both the epithelial (i.e. stationary) and migrating cancer stem cells had similar heterogeneous cell composition. Great histological similarity between a primary tumor and its respective metastases, noticed in many cases, also points to this concept. In addition to this bidirectional transition (EMT and MET), both stationary and migrating cancer stem cells could differentiate - the stationary into paraclones loosing the self-renewal capacity, and the migrating cancer stem cell into motile cells loosing the capacity to undergo MET (and, consequently, probably the capacity of growth on a secondary site).

In conclusion, the dynamic nature of cancer stem cells seems to be well substantiated, and we can be pretty sure that the details of it will continue to provide us with some surprise.

Acknowledgements: The work in the author's laboratory was supported by the grant No.MSM0021620819 "Replacement of and support to some vital organs" of the Ministry of Education of the Czech Republic and by the specific student research grant of the Charles University SVV-2012-264806. I am very grateful to Prof. Alain Zeimet for fruitful discussions over the manuscript.

\section{References}

[1] NOWELL PC. The clonal evolution of tumor cell populations. Science 1976; 194: 23-8. http://dx.doi.org/ $\underline{10.1126 / \text { science } 959840}$

[2] HATINA J, SCHULZ WA, FISCHER J, WAHL J, DEBATIN $\mathrm{KM}$ et al. Tumor stem cells - a new concept in tumor biology (In German). Dtsch. Med. Wochenschr. 2007; 132: 1629-32. http://dx.doi.org/10.1055/s-2007-984945

[3] HATINA J, SCHULZ WA Cancer stem cells - basic concepts. In: Encyclopedia of Life Sciences. Chichester: John Wiley \& Sons, 2008. http://dx.doi.org/10.1002/9780470015902. a0021164

[4] BUCHSTALLER J, QUINTANA E, MORRISON SJ Cancer stem cells. In: Mendelson J, Howley PM, Israel MA, Gray JW, Thompson CB, editors. The Molecular Basis of Cancer. Philadelphia: Sanders Elsevier, 2008: 141-154. http://dx.doi. org/10.1016/B978-141603703-3.10010-X

[5] VISVADER JE, LINDEMAN GJ Cancer stem cells in solid tumors: accumulating evidence and unresolved questions. Nat. Rev. Cancer 2008; 8: 755-68. http://dx.doi.org/10.1038/ $\underline{\operatorname{nrc} 2499}$

[6] KARLIC H, HERRMANN H, SCHULENBURG A, GRUNT TW, LAFFER $S$ et al. Tumor stem cell research - basis and challenge for diagnosis and therapy (In German). Wien. Klin. Wochenschr. 2010; 122: 423-36. http://dx.doi.org/10.1007/ s00508-010-1408-Z

[7] ALISON MR, LIM SM, NICHOLSON LJ Cancer stem cells: problems for therapy? J. Pathol. 2011; 223: 147-61. http:// dx.doi.org/10.1002/path.2793

[8] RAHMAN M, DELEYROLLE L, VEDAM-MAI V, AZARI $\mathrm{H}, \mathrm{ABD}-\mathrm{EL}-\mathrm{BARR} \mathrm{M}$ et al. The cancer stem cell hypothesis: failures and pitfalls. Neurosurgery 2011; 68: 531-45. http:// dx.doi.org/10.1227/NEU.0b013e3181ff9eb5

[9] SCHWARZ-CRUZ-Y-CELIS A, MELENDEZ-ZAJGLA J Cancer stem cells. Rev. Invest. Clin. 2011; 63: 179-86.

[10] PARK CH, BERGSAGEL DE, MCCUllOCH EA Mouse myeloma tumor stem cells: a primary cell culture assay. J. Natl. Cancer Inst. 1971; 46: 411-22.

[11] SOUTHAM CM AND BRUNSCHWIG A Quantitative studies of autotransplantation of human cancer. Cancer 1961; 14: 971-978.

[12] HAMBURGER AW, SALMON SE Primary bioassay of human tumor stem cells. Science 1977;197: 461-3. http://dx.doi. org/10.1126/science.560061

[13] LAPIDOT T, SIRARD C, VORMOOR J, MURDOCH B, HOANG T et al. A cell initiating human acute myeloid leukaemia after transplantation into SCID mice. Nature 1994; 367: 645-8. http://dx.doi.org/10.1038/367645a

[14] TAUSSIG DC, MIRAKI-MOUD F, ANJOS-AFONSO F, PEARCE DJ, ALLEN K et al. Anti-CD38 antibody-mediated clearance of human repopulating cells masks the heterogeneity of leukemia-initiating cells. Blood 2008; 112: 568-75. http://dx.doi.org/10.1182/blood-2007-10-118331

[15] FORBES SJ, ALISON MR Side population (SP) cells: taking center stage in regeneration and liver cancer? Hepatology 2006; 44: 23-6. http://dx.doi.org/10.1002/hep.21275 
[16] GOLEBIEWSKA A, BRONS NH, BJERKVIG R, NICLOU SP Critical appraisal of the side population assay in stem cell and cancer stem cell research. Cell Stem Cell 2011; 8: 136-47. http://dx.doi.org/10.1016/i.stem.2011.01.007

[17] ALISON MR, GUPPY NJ, LIM SM, NICHOLSON LJ Finding cancer stem cells: are aldehyde dehydrogenases fit for purpose? J Pathol. 2010; 222: 335-44. http://dx.doi.org/10.1002/ path. 2772

[18] MARCATO P, DEAN CA, GIACOMANTONIO CA, LEE PW Aldehyde dehydrogenase: Its role as a cancer stem cell marker comes down to the specific isoform. Cell Cycle 2011; 10: 1378-84. http://dx.doi.org/10.4161/cc.10.9.15486

[19] BARRANDON Y, GREEN H Three clonal types of keratinocyte with different capacities for multiplication. Proc. Natl. Acad. Sc.i U S A 1987; 84: 2302-6. http://dx.doi.org/10.1073/ pnas.84.8.2302

[20] LOCKE M, HEYWOOD M, FAWELL S, MACKENZIE IC Retention of intrinsic stem cell hierarchies in carcinoma-derived cell lines. Cancer Res. 2005; 65: 8944-50. http://dx.doi. org/10.1158/0008-5472.CAN-05-0931

[21] LI H, CHEN X, CALHOUN-DAVIS T, CLAYPOOL K, TANG DG PC3 human prostate carcinoma cell holoclones contain self-renewing tumor-initiating cells. Cancer Res. 2008; 68: 1820-5. http://dx.doi.org/10.1158/0008-5472.CAN-07$\underline{5878}$

[22] TAN L, SUI X, DENG H, DING M Holoclone forming cells from pancreatic cancer cells enrich tumor initiating cells and represent a novel model for study of cancer stem cells. PLoS One 2011; 6:e23383. http://dx.doi.org/10.1371/journal. pone. 0023383

[23] DONTU G, ABDALLAH WM, FOLEY JM, JACKSON $\mathrm{KW}$, CLARKE MF et al. In vitro propagation and transcriptional profiling of human mammary stem/progenitor cells. Genes Dev. 2003; 17: 1253-70. http://dx.doi.org/10.1101/ gad.1061803

[24] SINGEC I, KNOTH R, MEYER RP, MACIACZYK J, VOLK $B$ et al. Defining the actual sensitivity and specificity of the neurosphere assay in stem cell biology. Nature Methods 2006; 3: 801 - 806. http://dx.doi.org/10.1038/nmeth926

[25] GRIMSHAW MJ, COOPER L, PAPAZISIS K, COLEMAN JA, BOHNENKAMP HR et al. Mammosphere culture of metastatic breast cancer cells enriches for tumorigenic breast cancer cells. Breast Cancer Res. 2008; 10:R52. http://dx.doi. org/10.1186/bcr2106

[26] SCHEEL C, WEINBERG RA Phenotypic plasticity and epithelial-mesenchymal transitions in cancer and normal stem cells? Int. J. Cancer 2011; 129: 2310-4. doi: 10.1002/ijc.26311 http://dx.doi.org/10.1002/ijc.26311

[27] PANAGIOTAKOS G, TABAR V Brain tumor stem cells. Curr. Neurol. Neurosci. Rep. 2007; 7: 215-20. http://dx.doi. org/10.1007/s11910-007-0033-3

[28] BARKER N, VAN ES JH, KUIPERS J, KUJALA P, VAN DEN BORN $\mathrm{M}$ et al. Identification of stem cells in small intestine and colon by marker gene Lgr5. Nature 2007; 449: 1003-7. http://dx.doi.org/10.1038/nature06196

[29] BARKER N, RIDGWAY RA, VAN ES JH, VAN DE WETERING M, BEGTHEL $\mathrm{H}$ et al. Crypt stem cells as the cells-of-origin of intestinal cancer. Nature 2009; 457: 608-11. http://dx.doi.org/10.1038/nature07602

[30] PIETRAS K, OSTMAN A Hallmarks of cancer: interactions with the tumor stroma. Exp. Cell Res. 2010; 316: 1324-31. http://dx.doi.org/10.1016/j.yexcr.2010.02.045

[31] BRABLETZ T, JUNG A, SPADERNA S, HLUBEK F, KIRCHNER T Opinion: migrating cancer stem cells - an integrated concept of malignant tumor progression. Nat. Rev. Cancer 2005; 5: 744-9. http://dx.doi.org/10.1038/ $\underline{\operatorname{nrc1694}}$

[32] HERMANN PC, HUBER SL, HERRLER T, AICHER A, ELLWART JW et al. Distinct populations of cancer stem cells determine tumor growth and metastatic activity in human pancreatic cancer. Cell Stem Cell 2007; 1: 313-23. http:// dx.doi.org/10.1016/j.stem.2007.06.002

[33] MANI SA, GUO W, LIAO MJ, EATON EN, AYYANAN A, ZHOU AY et al. The epithelial-mesenchymal transition generates cells with properties of stem cells. Cell 2008; 133: 704-15. http://dx.doi.org/10.1016/j.cell.2008.03.027

[34] WELLNER U, SCHUBERT J, BURK UC, SCHMALHOFER $\mathrm{O}, \mathrm{ZHU} \mathrm{F}$ et al. The EMT-activator ZEB1 promotes tumorigenicity by repressing stemness-inhibiting microRNAs. Nat. Cell Biol. 2009; 11: 1487-95. http://dx.doi.org/10.1038/ $\underline{\text { ncb1998 }}$

[35] KALLURI R, WEINBERG RA The basics of epithelialmesenchymal transition. J. Clin. Invest. 2009; 119: 1420-8. http://dx.doi.org/10.1172/JCI39104

[36] YANG MH, HSU DS, WANG HW, WANG HJ, LAN HY et al. Bmil is essential in Twist1-induced epithelial-mesenchymal transition. Nat. Cell Biol. 2010; 12: 982-92. http://dx.doi. org/10.1038/ncb2099

[37] WU KJ, YANG MH Epithelial-mesenchymal transition and cancer stemness: the Twist1-Bmil connection. Biosci. Rep. 2011; 31: 449-55. http://dx.doi.org/10.1042/ BSR20100114

[38] COVELLO KL, KEHLER J, YU H, GORDAN JD, ARSHAM AM et al. HIF-2alpha regulates Oct-4: effects of hypoxia on stem cell function, embryonic development, and tumor growth. Genes Dev. 2006; 20: 557-70. http://dx.doi.org/ $\underline{10.1101 / \mathrm{gad} .1399906}$

[39] OCANA OH, NIETO MA Epithelial plasticity, stemness and pluripotency. Cell Res. 2010; 20: 1086-8. http://dx.doi. org/10.1038/cr.2010.127

[40] CHANG CC, SHIEH GS, WU P, LIN CC, SHIAU AL et al. Oct-3/4 expression reflects tumor progression and regulates motility of bladder cancer cells. Cancer Res. 2008;68:6281-91. http://dx.doi.org/10.1158/0008-5472. CAN-08-0094

[41] STEFANOVIC S, PUCEAT M The dual role of OCT4 (In French). Med. Sci. (Paris) 2010; 26: 411-6. http://dx.doi. org/10.1051/medsci/2010264411

[42] SHACKELFORD DB, SHAW RJ The LKB1-AMPK pathway: metabolism and growth control in tumor suppression. Nat. Rev. Cancer 2009; 9: 563-75. http://dx.doi.org/10.1038/ $\underline{\operatorname{nrc} 2676}$

[43] CHAFFER CL, BRUECKMANN I, SCHEEL C, KAESTLI AJ, WIGGINS PA et al. Normal and neoplastic nonstem cells can 
spontaneously convert to a stem-like state. Proc. Natl. Acad. Sci. U S A. 2011; 108: 7950-5. http://dx.doi.org/10.1073/ pnas. 1102454108

[44] HE K, XU T, GOLDKORN A Cancer cells cyclically lose and regain drug-resistant highly tumorigenic features characteristic of a cancer stem-like phenotype. Mol. Cancer Ther. 2011; 10: 938-48. http://dx.doi.org/10.1158/1535-7163.MCT-10$\underline{1120}$
[45] PIETRAS A Cancer stem cells in tumor heterogeneity. Adv. Cancer Res. 2011; 112: 255-81. http://dx.doi.org/10.1016/ B978-0-12-387688-1.00009-0

[46] BIDDLE A, LIANG X, GAMMON L, FAZIL B, HARPER LJ et al. Cancer stem cells in squamous cell carcinoma switch between two distinct phenotypes that are preferentially migratory or proliferative. Cancer Res. 2011; 71: 5317-26. http://dx.doi.org/10.1158/0008-5472.CAN-11-1059 